\title{
FUEL CONSUMPTION, WORK TIME EXPENDITURES AND WINTER WHEAT YIELD IN CASE OF NON-TILLAGE AND STRIP SOIL CULTIVATION
}

\author{
Tomasz Piskier ${ }^{*}$ \\ Agri-biotechnology Department, Koszalin University of Technology
}

"Corresponding author: e-mail: piskier@poczta.onet.pl

\begin{tabular}{|c|c|}
\hline ARTICLE INFO & ABSTRACT \\
\hline $\begin{array}{l}\text { Article history: } \\
\text { Received: April } 2017 \\
\text { Received in the revised form: } \\
\text { May } 2017 \\
\text { Accepted: May } 2017 \\
\end{array}$ & $\begin{array}{l}\text { A single-factor field experiment concerned calculation of fuel con- } \\
\text { sumption, time expenditure of the working time of machines, and } \\
\text { winter wheat yield size in three technologies of soil cultivation. Fuel } \\
\text { consumption in the tillage and non-tillage technology was comparable } \\
\text { and amounted approximately to } 31 \mathrm{l}^{\cdot} \mathrm{ha}^{-1} \text {, but the highest consumption }\end{array}$ \\
\hline $\begin{array}{l}\text { Key words: } \\
\text { tillage cultivation, } \\
\text { non-tillage cultivation, } \\
\text { strip cultivation, } \\
\text { fuel consumption, } \\
\text { work expenditure, } \\
\text { yield }\end{array}$ & $\begin{array}{l}\text { was generated by basic soil cultivation (tillage or heavy cultivation } \\
\text { cultivator). Fuel consumption in the strip cultivation technology was } \\
\text { the lowest and it was } 23.0 \mathrm{l}^{-} \mathrm{ha}^{-1} \text {. Non-tillage cultivation allowed } \\
\text { reduction of the time necessary to carry out the wheat cultivation } \\
\text { technology by } 28.8 \% \text { (in comparison to tillage cultivation). On the } \\
\text { other hand, strip cultivation allowed reduction of the total time of } \\
\text { machines operation by } 48.5 \% \text { (in comparison to tillage cultivation). } \\
\text { The yield of winter wheat cultivated in the non-tillage technology was } \\
\text { at the average by } 4 \% \text { better than the one cultivated in tillage cultiva- } \\
\text { tion. The highest yield of seed ( } 7.63 \mathrm{t}^{-1} \text { ha }{ }^{-1} \text { ) was obtained in the strip } \\
\text { cultivation technology (by } 6.7 \% \text { in comparison to tillage cultivation). }\end{array}$ \\
\hline
\end{tabular}

\section{Introduction and objective of study}

Intensive mechanical cultivation of soil causes its degradation. This relation induces searching for alternative methods of soil cultivation which helps to protect environment and biodiversity (Kogut, 2011; Weber 2010). Replacement of tillage cultivation with preserving cultivation technologies causes limitation of soil compaction and its protection against water and wind erosion. Elimination of tillage cultivation and replacing it with non-tillage cultivation causes limitation of agricultural production costs and reduction of energy expenditures (Cudzik et al., 2012). The amount of fuel consumption during cultivation treatments depends on the soil type, manner of impact of working elements on soil, depth of their work and weather conditions (Morris et al., 2010). Tillage, which constitutes a basic treatment of the tillage technology, decides considerably on the size of consumed fuel, since it takes even $20 \mathrm{l}^{\cdot} \mathrm{ha}^{-1}$ (Jaskulski et al., 2013). Reduction of the amount of consumed fuel in the non-tillage technologies is not clear, and research results are different. There are research which indicate slight limitation of fuel consumption after the use of non-tillage technologies (Jaskulski et al., 2013). Majority of authors states, on the other hand, a very 
clear limitation of fuel consumption after the use of non-tillage cultivation (Sørensen et al., 2014, Cudzik et al., 2012). Reduction of fuel consumption in non-tillage technologies does not mean reduction of plant yield. In the tests carried out by Cudzik et al. (2012), reduction of fuel consumption was approximately $35 \%$ and the wheat yield was lower by $9 \%$. Nontillage cultivation requires noticeably lower work time expenditure for its performance; this feature is particularly important in commodity agricultural farms (Orzech et al., 2009).

The objective of the research was to determine the impact of non-tillage and strip soil cultivation on the fuel consumption size and efficiency of fuel consumption. Moreover, the impact of applied technologies of soil cultivation and the size of winter wheat yield cultivated on medium-compacted 4 class soil was determined.

\section{Material and research methods}

A single-factor field experiment was carried out in 2014-2015 on the $4^{\text {th }}$ averagecompacted soil in Madgarby near Kętrzyn. The size of fuel consumption and work time expenditure was investigated in three technologies of winter wheat production:

- tillage technology (control) - skimming with a disc harrow Carrier 650, basic cultivation with a 5-furrow rotational plough, basic cultivation made with Amazone suspended spreader, sowing carried out with Rapid 600 spreader,

- tillage technology (control) - skimming with a disc harrow Carrier 650, basic cultivation with a 5-furrow rotational plough, basic cultivation made with Amazone suspended distributor sowing carried out with Rapid 600 distributor,

- strip technology - skimming with a disc harrow Carrier 650, basic cultivation, fertilizer spreading and sowing of seeds with StripDrill aggregate.

Basic cultivation depth was not varied, and in all cases amounted to $22 \mathrm{~cm}$. During skimming (Cerrier 650) and sowing of seeds (Rapid 600) tractor JD 8430 - 305KM cooperated with aggregates, in soil cultivation (plough or TopDown 400) and in strip cultivation (StripDrill) Xserion $500 \mathrm{KM}$ was applied, during fertilization Ursus 4512 cooperated with a spreader. In case of wheat cultivation, mineral fertilization in the amount of $160 \mathrm{~kg}^{-1} \mathrm{ha}^{-1}$ of nitrogen (N), $50 \mathrm{~kg} \cdot \mathrm{ha}^{-1}$ of phosphorus (P), $40 \mathrm{~kg} \cdot \mathrm{ha}^{-1}$ of potassium (K) was applied. The size of fertilization, applied crop protection substances and the amount of sowing were not varied on the investigated fields. In the field tests, winter wheat of Julisu cultivar was sowed in the amount of $180 \mathrm{~kg} \cdot \mathrm{ha}^{-1}$.

Field experiment was carried out on the 12 ha field where three test areas, uniform with regard to the shape and dimension, each 4 ha, were determined. The research on the machines performance was carried out with simplified timing, and fuel consumption was carried out directly (with a full tank method). Before the agrotechnical treatment was started, the cooperating tractor was fully refuelled. After the treatment was finished, it was fully refuelled and the difference was accepted as an amount of consumed fuel for a given treatment. Fuel consumption in a particular technology was determined as a sum of fuel for performance of particular agrotechnical treatments. By analogy, time needed to carry out a specific technology was calculated. The size of winter wheat yield was determined through direct yield weighting after combine cultivation individually from each test area. 
Fuel consumption...

\section{Research results}

Compared technologies of winter wheat cultivation may be divided into two groups on account of the number of treatments. The first group includes the tillage and non-tillage technology. Both carried out the same number of single agrotechnical treatments. Since, skimming, basic soil cultivation, basic fertilization, and sowing of seeds, were carried out there. These technologies differ only with selection of a tool that carried out basic cultivation of soil. In case of the tillage technology it is a plough, in case of the non-tillage technology, heavy cultivator. It results with slight differences in the total fuel consumption in particular technologies. Skimming, sowing of seeds and basic fertilization required consumption of the same amount of fuel regardless the applied technology. Fuel consumption in case of these treatments was in total $12.7 \mathrm{l}^{\mathrm{h}} \mathrm{ha}^{-1}$. Amount of fuel consumed on ploughing was at the level of $18.3 \mathrm{l} \cdot \mathrm{ha}^{-1}$ and for non-tillage cultivation it was $17.8 \mathrm{l} \cdot \mathrm{ha}^{-1}$. In total, the tillage technology $31.0 \mathrm{l}^{\mathrm{h}} \mathrm{ha}^{-1}$ of fuel was consumed and in non-tillage technology consumption was lower by $1.6 \%$ and it was $30.5 \mathrm{l}^{-1} \mathrm{ha}^{-1}$. On the other hand, consumption for basic cultivation was $59 \%$ in case of the tillage technology, and $58.4 \%$ in non-tillage technology (table1).

Table 1.

Fuel consumption in investigated technologies of soil cultivation $\left(l \cdot h a^{-1}\right)$

\begin{tabular}{lcccc}
\hline Treatment /machine & $\begin{array}{c}\text { Performance } \\
\left(\mathrm{ha}^{-1} \mathrm{~h}\right)\end{array}$ & $\begin{array}{c}\text { Tillage } \\
\text { technology }\end{array}$ & $\begin{array}{c}\text { Non-tillage } \\
\text { technology }\end{array}$ & $\begin{array}{c}\text { Strip } \\
\text { cultivation }\end{array}$ \\
\hline Skimming /Carrier 650 & 5.5 & 6.9 & 6.9 & 6.9 \\
\hline $\begin{array}{l}\text { Soil cultivation / } \\
\text { 5-furrow plough }\end{array}$ & 1.5 & 18.3 & & \\
\hline $\begin{array}{l}\text { Soil cultivation / } \\
\text { TopDown 400 }\end{array}$ & 3.0 & & 5.2 & 17.8 \\
\hline $\begin{array}{l}\text { Sowing of seeds/ } \\
\text { Rapid 600 }\end{array}$ & 5.0 & 5.2 & & \\
\hline $\begin{array}{l}\text { Cultivation, sowing. } \\
\text { fertilization/ }\end{array}$ & 2.5 & & 0.6 & 23.0 \\
\hline $\begin{array}{l}\text { StripDrill aggregate } \\
\text { Amasic fertilization/ }\end{array}$ & 12.5 & 31.0 & 30.5 & \\
\hline Together & & &
\end{tabular}

Strip cultivation with StripDrill unit is a second conventional group. The strip cultivation technology was limited to two working crossings through a field. During the first one, skimming was performed and the other was carried out with a strip cultivation unit that performs basic soil cultivation during one working crossing, introduces a basic dose of mineral fertilizers and sows seeds. This situation has a basic meaning for amount of consumed fuel. Skimming, as a treatment carried out on the entire field with the same machine, did not differentiate the fuel consumption which was $6.9 \mathrm{l} \cdot \mathrm{ha}^{-1}-$ it is the same amount as in case of the remaining technologies. StripDrill unit is equipped with working chisels distributed every $33.2 \mathrm{~cm}$. Width of a single chisel is $2.5 \mathrm{~cm}$. Such type of the structure causes that this machine makes a very small working resistance and thus, has a relatively small 
fuel consumption per an area unit. During the tests, the average fuel consumption for strip cultivation was $16.1 \mathrm{l} \cdot \mathrm{ha}^{-1}$. Total fuel consumption in the strip cultivation technology was lower than consumption in the tillage technology by $25.8 \%$ and it was $23.0 \mathrm{l}^{\cdot} \mathrm{ha}^{-1}$ (table1).

Reduction of fuel consumption resulting from the non-tillage technologies was emphasised also by Golka and Ptaszyński (2014). They proved that reduction of fuel consumption in case of a complex assessment of the simplified technology was approx. 56\%. Similar relations were stated by Czarnocki et al., (2008). In the papers they also paid attention to the fact that differences in the value of fuel consumption reduction result the most often from the type of used machines for non-tillage cultivation and depth of their operation.

Big-area farms more and more often deal with the problem of maintaining deadlines of agrotechnical treatments and, as a consequence, of sowing. This relations induce searching for new more efficient technologies. Compared cultivation technologies clearly differ with regard to work time expenditures, which is necessary for their performance. In the nontillage technology time for all agrotechnical treatments that aim at preparation of soil for sowing, sowing itself and basic fertilization was at the average of $66 \mathrm{~min} \cdot \mathrm{ha}^{-1}$. Ploughing takes the longest time ( $39 \mathrm{~min}^{-h^{-1}}{ }^{-1}$ ) because it constitutes over $59 \%$ of the time indispensable to perform this technology (table 2). The non-tillage technology did not differ from the tillage technology with regard to the work time needed to carry out skimming, fertilization and sowing. This difference was related to one treatment of basic cultivation, namely, the use of a heavy cultivator. Basic cultivation took $20 \mathrm{~min}^{-1} \mathrm{a}^{-1}$ and this value was $42.6 \%$ of the total time needed to carry out the non-tillage technology. The total sum of time needed to complete the entire non-tillage technology with sowing and basic fertilization is $47 \mathrm{~min}$ ha ${ }^{1}$. Using this technology, $28.8 \%$ of time was saved in comparison to tillage cultivation (table 2). With regard to the limited number of crossings on a field, the strip cultivation technology is a technology which requires the lowest work time expenditures for its performance. Skimming in this technology takes the same time as in the remaining technologies. However, cultivation, fertilization, and sowing takes place in one working crossing, which decisively influences the work expenditures for this technology. In total, the strip cultivation technology required $34 \mathrm{~min} \cdot \mathrm{ha}^{-1}$ and this value is lower than in case of tillage cultivation by $48.5 \%$. Many authors also confirm the results obtained in the paper concerning lower work time expenditures for soil cultivation in non-tillage systems (Czarnocki et al., 2008; Golka and Ptaszyński, 2014). The applied technologies were not without the impact on variability of the wheat seed yield (Table 3 ). The yield obtained in the tillage technology was $7.15 \mathrm{t}^{-1} \mathrm{a}^{-1}$ and in non-tillage technology the average yield was higher by $4 \%$ and it was $7.44 \mathrm{t}^{\cdot} \mathrm{ha}^{-1}$.

Wheat cultivated in the strip technology had the best yield. The average yield was $7.63 \mathrm{t}^{\mathrm{t}} \mathrm{h}^{-1}$ and was higher than the one determined during control (plough cultivation) by $6.7 \%$. The compared technologies differ with regard to the amount of consumed fuel and the size of the obtained yield. The amount of the consumed fuel for preparation of a stand, fertilization and sowing of plants in the tillage technology was $31.0 \mathrm{l} \cdot \mathrm{ha}^{-1}$, which per one tonne of yield gave $4.34 \mathrm{l}$. The non-tillage technology had considerably lower fuel consumption. 
Fuel consumption...

Table 2.

Time used for agrotechnical treatments in investigated technologies of soil cultivation $\left(\min . h a^{-1}\right)$

\begin{tabular}{lcccc}
\hline Treatment /machine & $\begin{array}{c}\text { Performance } \\
\left(\mathrm{ha}^{-1} \mathrm{~h}^{-}\right)\end{array}$ & $\begin{array}{c}\text { Tillage } \\
\text { technology }\end{array}$ & $\begin{array}{c}\text { Non-tillage } \\
\text { technology }\end{array}$ & $\begin{array}{c}\text { Strip } \\
\text { cultivation }\end{array}$ \\
\hline $\begin{array}{l}\text { Skimming / } \\
\text { Carrier 650 }\end{array}$ & 5.5 & 10 & 10 & 10 \\
\hline $\begin{array}{l}\text { Soil cultivation / } \\
\text { 5-furrow plough }\end{array}$ & 1.5 & 39 & 20 & \\
\hline $\begin{array}{l}\text { Soil cultivation / } \\
\text { TopDown 400 }\end{array}$ & 3.0 & 12 & 12 & 24 \\
\hline $\begin{array}{l}\text { Sowing of seeds/ } \\
\text { Rapid 600 }\end{array}$ & 5.0 & & & \\
\hline $\begin{array}{l}\text { Cultivation, sowing, } \\
\text { fertilization / } \\
\text { StripDrill aggregate }\end{array}$ & 2.5 & 5 & 5 & 34 \\
\hline $\begin{array}{l}\text { Basic fertilization } \\
\text { Amazone spreader }\end{array}$ & 12.5 & 66 & 47 & \\
\hline \begin{tabular}{l} 
Together \\
\hline
\end{tabular} & & & & \\
\hline
\end{tabular}

At the same time, however, the seed yield was higher. These relations caused that at the average $4.10 \mathrm{l}$ of fuel was consumed for production of one tonne of winter wheat seed in this technology. The best efficiency, understood as fuel consumption for production of one tonne of wheat seed, was determined in the strip cultivation technology. Production of one tonne of seed consumed at the average of $3.01 \mathrm{l}$ of fuel (Table 3). This value is lower than the one found in tillage cultivation by $30.6 \%$.

Table 3.

Impact of cultivation technology of soil on winter winter yield and fuel consumption on production of one tonne of seed

\begin{tabular}{lccc}
\hline Investigated parameter & $\begin{array}{c}\text { Tillage } \\
\text { technology }\end{array}$ & $\begin{array}{c}\text { Non-tillage } \\
\text { technology }\end{array}$ & $\begin{array}{c}\text { Strip } \\
\text { cultivation }\end{array}$ \\
\hline Seed crop $\left(t \cdot \mathrm{ha}^{-1}\right)$ & 7.15 & 7.44 & 7.63 \\
\hline $\begin{array}{l}\text { Fuel consumption } \\
\text { for production of one } \\
\text { tonne of seed }\left(\mathrm{l} \cdot \mathrm{t}^{-1}\right)\end{array}$ & 4.34 & 4.10 & 3.01 \\
\hline
\end{tabular}

Variability of plant yield, including winter wheat, as a result of simplified cultivation application is not explicit and depends on the manner of its performance and the applied equipment. Many authors indicate that the application of the non-tillage technology enables limitation of work and fuel expenditures while maintaining a comparable size of yield to the one obtained in tillage systems (Gawęda et al., 2006). For example, Cudzik et al., 2012 showed reduction of wheat yield as a consequence of non-tillage cultivation application. 2012. However, they used a traditional non-tillage cultivator and not a unit dedicated for non-tillage cultivation. Similar relations were stated by Czarnocki et al., (2008) and Orzech 
et al., (2009). In case of typical non-tillage cultivation units, the size of a grain yield is not reduced and in some cases explicitly raises (Piskier and Sekutowski, 2014).

\section{Conclusions}

1. Under the conditions of average-compacted soil, non-tillage technology does not diversify explicitly the amount of the consumed fuel for cultivation of winter wheat, but explicitly reduces the work expenditure that is necessary for its performance (by $29 \%$ in comparison to non-tillage cultivation).

2. Application of strip cultivation, in comparison to tillage cultivation, causes reduction of the amount of the consumed fuel (by 28.5\%) and work expenditures (by 48.5\%) incurred for soil cultivation for winter wheat

3. The amount of winter wheat yield cultivated in the tillage technology was $7.15 \mathrm{t} \cdot \mathrm{ha}^{-1}$. The average seed yield in the non-tillage technology was $7.44 \mathrm{t}^{\cdot h} \mathrm{ha}^{-1}$ (higher by $4 \%$ than the one obtained in tillage cultivation). The biggest seed yield $\left(7.63 \mathrm{t}^{\cdot} \mathrm{ha}^{-1}\right)$ was obtained in the strip cultivation technology. It was higher than the one obtained in the tillage technology by $6.7 \%$.

4. The use of fuel in the strip technology is the most effective. Fuel consumption for production of 1 tonne of seed is $3.01 \mathrm{l}$, and in the non-tillage technology, it is $4 \mathrm{l}$.

\section{References}

Cudzik, A., Białczyk, W., Czarnecki, J., Brennensthul, M., Kaus, A. (2012). Ocena systemów uprawy w aspekcie zużycia paliwa, plonowania roślin i właściwości gleby. Inżynieria Rolnicza, 2(137) T.2, 17-27.

Czarnocki, S., Starczewski J., Kapela K. (2008). Porównanie zużycia paliwa i czasu pracy przy kilku alternatywnych technologiach przygotowania roli do siewu. Inżynieria Rolnicza, 4(102), 209-2015.

Gawęda, D., Szymankiewicz, K., Harasim, E. (2006). Efektywność energetyczna różnych systemów uprawy roli w 3-polowym zmianowaniu. Pamiętnik Puławski. 142,.105-116.

Golka, W., Ptaszyński S. (2014). Nakłady na uprawę roli w technologii zachowawczej i tradycyjnej. Problemy Inżynierii Rolniczej, 3(85), 31-47.

Jaskulski, D., Jaskulska, I., Kotwica, K., Gałęzewski, L., Wasilewski, P. (2013). Zużycie paliwa na uprawę roli w zależności od stopnia jej uproszczenia i przedplonu w zmianowaniu roślin. Inżynieria Rolnicza, 3(145), 109-116.

Kogut, Z. (2011). Jakość pracy narzędzi w uprawie gleby z wykorzystaniem mulczu. Postępy Nauk Rolniczych, 3, 89-103.

Morris, N.L., Miller, P.C.H., Orson, J.H., Froud-Williams, R.J. (2010). The adoption of noninversion tillage systems in the United Kingdom and the agronomic impact on soil, crops and the environment - a review. Soil and Tillage Research, 108, 1-15.

Orzech, K., Marks, M., Dragańska, E., Stępień, A. (2009). Plonowanie pszenicy ozimej w zależności od warunków pogodowych i różnych sposobów uprawy gleby średniej. Annales Universitatis Mariae Curie-Skłodowska, Vol. LXIV(4), 122-129.

Piskier, T., Sekutowski, T.R. (2014). Środowiskowe i produkcyjne skutki stosowania bezorkowych systemów uprawy roli. Studia i Raporty IUNG-PIB, 36(10), 69-90.

Sørensen, C.G., Halberg, N., Oudshoorn, F.W., Petersen, B.M., Dalgaard, R. (2014). Energy inputs and GHG emissions of tillage systems. Biosystems Engineering. Vol. 120, 2-14.

Weber, R. (2010). Wpływ okresu stosowania systemów bezpłużnych na właściwości gleby. Postępy Nauk Rolniczych, 1, 63-75. 
Fuel consumption...

\section{ZUŻYCIE PALIWA, NAKLADY CZASU PRACY ORAZ PLONOWANIE PSZENICY OZIMEJ W BEZORKOWEJ I PASOWEJ UPRAWIE ROLI}

Streszczenie. Jednoczynnikowe doświadczenie łanowe dotyczyło określenia zużycia paliwa, nakładu czasu pracy maszyn oraz wielkości plonowania pszenicy ozimej w trzech technologiach uprawy roli. Zużycie paliwa w technologii orkowej i bezorkowej było porównywalne i wynosiło około $31 \mathrm{l} \cdot \mathrm{ha}^{-1}$, przy czym największe zużycie generowała podstawowa uprawa gleby (orka lub ciężki kultywator uprawowy). Zużycie paliwa w technologii uprawy pasowej było najmniejsze i wynosiło $23,0 \mathrm{l} \cdot \mathrm{ha}^{-1}$. Zastosowanie uprawy bezorkowej pozwoliło na zmniejszenie czasu potrzebnego do wykonania technologii uprawy pszenicy o $28,8 \%$ (w porównaniu do uprawy orkowej). Natomiast uprawa pasowa pozwoliła na zredukowanie łącznego czasu pracy maszyn o 48,5\% (w porównaniu do uprawy orkowej). Pszenica ozima uprawiana $w$ technologii bezorkowej plonowała przeciętnie o $4 \%$ lepiej od uprawianej $\mathrm{w}$ technologii orkowej. Największy plon ziarna $\left(7,63 \mathrm{t} \cdot \mathrm{ha}^{-1}\right)$ uzyskano $\mathrm{w}$ technologii uprawy pasowej (o 6,7\% w porównaniu do uprawy orkowej).

Słowa kluczowe: uprawa orkowa, uprawa bezorkowa, uprawa pasowa, zużycie paliwa, nakłady pracy, plon 